\title{
Proceeding
}

Supplementary Issue: Autumn Conferences of Sports Science. Costa Blanca Sports Science Events, 18-19 December 2020. Alicante, Spain.

\section{Motor activities and paddle during COVID-19}

\author{
ANTONIO ASCIONE \\ University of Bari "Aldo Moro", Bari, Italy
}

\begin{abstract}
The purpose of this research work is to highlight the contribution that a motor and sports practice such as Paddle can provide during a particular period like the current one, marked by the presence of the COVID-19 virus which negatively affects the development of social, relational, and educational aspects of any person practicing this sport. This paper aims to highlight the educational importance of the movement through the sports discipline of Paddle, especially in a negative period like the one we are going through, due to the health and social pandemic of "Corona Virus".
\end{abstract}

Keywords: Sport; Education; Paddle; Socialization; COVID-19.

\section{Cite this article as:}

Ascione, A. (2021). Motor activities and paddle during COVID-19. Journal of Human Sport and Exercise, 16(2proc), S269-S276. doi:https://doi.org/10.14198//hse.2021.16.Proc2.12

Corresponding author. University of Bari “Aldo Moro", Bari, Italy.

E-mail: antonio.ascione@uniba.it

Abstract submitted to: Autumn Conferences of Sports Science. Costa Blanca Sports Science Events, 18-19 December 2020. Alicante, Spain.

JOURNAL OF HUMAN SPORT \& EXERCISE ISSN 1988-5202

(c) Faculty of Education. University of Alicante

doi:10.14198/jhse.2021.16.Proc2.12 


\section{INTRODUCTION}

Paddle is a very entertaining game that can be played by people of any age, sex, technical and physical condition. It is a very rapidly spreading sport in Italy for some of its characteristics: simplicity of play, accessibility to all (athletes and not), guaranteed fun, and finally, for simple chances to meet and get together.

Paddle is a sport that, over time, has increasingly assumed an educational, relational, and social value for people, showing a significant educational and social growth, despite a period of pandemic due to COVID-19 that has compromised the practice of any sports activity.

This work aims to highlight the educational and social values of the game of Paddle, and the importance that they assume in terms of social life.

\section{THE GAME OF PADDLE: HISTORY AND RULES}

The game of Paddle originated in Mexico in the 70's, although some legends believe it was born on board English sailing ships in the nineteenth century, where sailors, due to boredom, experimented with a particular game to be played in the hold of the ship with oars and a ball, which bounced from one side to the other with the help of the walls. According to others, this game originated in 1898, in its primitive form, thanks to the New York reverend Frank Beal who named it Paddle Tennis, as a recreational activity initially reserved for children. The term Paddle derives from the solid-surface racket from which the game takes its name. A solid wooden racket was used to play the game, while the court was surrounded by metal fences. However, others claim that Paddle was born in the United States at the beginning of the '20s, as various people challenged each other in the public parks of New York in a strange variant of tennis with rackets that resembled oars, and it then evolved into the sport we know today, invented by Frank Beal, with a wooden floor and metal nets all around. However, these are only legends, and the official version states that the sport was invented in 1969 by the Mexican Enrique Corcuera who wanted to build a tennis court in his house, and since there were walls right next to the space available to draw the court, he conceived the idea of considering the walls as an integral part of the court itself. Corcuera later regulated the new game and called it Paddle.

Paddle is one of the most popular sports in Latin America, especially in Argentina and in Spain with 4.5 million amateurs, and it is also quite popular in Portugal and Sweden. In the last 5 years this sport has also seen a strong growth in Italy, where the number of fields has increased by over $800 \%$. The first court in Italy was created in 1991 in Costabissara, in the province of Vicenza; it then spread to the Region of Emilia Romagna in the ' 90 s and to the circles of the Italian capital from 2013 onwards. In fact, even today, one out of three structures are located in Lazio, but other large cities such as Milan, Turin and Palermo are rapidly investing in the construction of new courts for the growing number of practitioners in this sport. Currently, in Italy, the Italian Paddle Game Federation is managed and organized by the Italian Tennis Federation.

The rules of the game of Paddle are very similar to those of tennis: there is a solid plate racket with holes, it is compact and is $45-50$ centimetres long, and the balls are similar to those used for tennis. The court is 20 meters long and 10 meters wide, with a delimiting wall that is 3 meters high on most sides and 4 meters high on the back side. The net, located in the middle of the court, is 10 meters long and is 88 centimetres high in the middle, and 92 centimetres high at the ends. It is played by four people, but it is not rare to see only two people playing. The scoring is the same as in tennis: each "game" involves scoring a succession of points ranging from 15-0 to 40-0. When a pair wins the first point, their score is 15 ; if they win the second point, their score is 30; if they win the third point, their score is 40 ; and with the fourth point won, they win the game. In 
case of a 40-40 score, the game is "tied"; the following point is called "advantage" in favour of the winner and, if the same couple wins the following point, they also win the game; if they lose it, the game becomes "tied" again and goes on until one of the two pairs wins two consecutive points after the "tie". The pair that wins 6 games first, with at least a two-game lead, wins the match; in case of a 5-game tie, two more games must be played until a 7-5 win, but if there is a 6 -game tie, there is a tie-break.

The point is scored when:

- $\quad$ The ball touches the walls of the opponent's court and bounces twice on the floor.

- The ball bounces correctly into the opponent's field and, by going beyond the limits of the field, hits some foreign element or object or bounces twice before being repelled.

- A player can hit the ball and make it bounce in the other player's half of the field and go out of the side game fence, making it unreachable.

Vice versa, the point is lost when:

- The ball bounces twice in the field before being hit.

- A player hits the ball on the fly that has not passed the net yet.

- A player, by hitting the ball for the rebound, makes it touch on his/her own court.

- $\quad$ The ball is touched by the player and not by the racket.

- $\quad$ The player touches or hits the ball more than once while launching it back.

- $\quad$ Both players of a pair (in the doubles) hit the ball simultaneously or consecutively.

\section{THE EDUCATIONAL AND SOCIAL FUNCTIONS OF THE GAME OF PADDLE}

The verb to educate comes from the Latin word "educere", which means to lead out, namely to try to bring out the truth from the person instead of instilling it into him or her; this assumption highlights the need to use the sports activity as a fundamental element both from an educational and social-relational point of view. Any types of sports activity have these peculiarities, and thus even a sport like Paddle, which has been spreading in Italy only in recent years, possesses them. It is thanks to these characteristics, perhaps even more evident in Paddle, in addition to the simplicity of the game, that the surprising popularity that this sport is having can be explained. It demonstrates that it possesses a wide range of values that can be developed and increased, going well beyond the educational aspect. In addition, it has economic, social, entertainment, pathology prevention, legality, democracy, and promotional purposes, highlighting the fact that, in social life, all of these values must be developed over time by taking into consideration not only the mind, but also the body. Paddle can be defined as a type of ambivalent and multifaceted sports activity, in the sense that it can be understood both as a meeting place between friends, and simultaneously as a place of confrontation, overpowering and selfishness too. To define it simply, it could be said that it is necessary to exploit one's own physical and psychic energies in order to satisfy one's own sense of self-efficacy, capable of creating pleasure in being involved in the game.

To broaden this great range of values, thanks to the practice of the game of Paddle, means therefore to favour the fact that they become an orientation for the young adult of the future, having not only a simple educational value but also an important ethical function for understanding reality, favouring the increase and enrichment of what can be called "ethical thinking". This process of transmission, applicable also and above all in sports contexts, creates a real educational system with both educators and students, and the instrument through which these educational values are transmitted is the game of Paddle. It is evident that this mode of transmission is valid for all the actors who participate in this educational action, in which the educationalsocial component has great importance for this sports activity, understood as a physical activity for the 
individual's well-being and health, as competition, as a continuous drive to improve oneself, and at the same time it becomes an instrument for the optimization of ethical principles common to daily life, such as the communication and social spheres.

Paddle is a sport practiced by children, men, and women of all ages, thanks to a non-excessive physical effort, but also because it is very easy to play. In fact, it can be played right from the first match, thus avoiding possible moments of difficulty that can create the embarrassment typical of the first matches performed by amateur players.

As mentioned, the game of Paddle is like tennis, but is much more active and dynamic, which makes it more fun and enjoyable especially for children, and it is for this reason that it quickly becomes part of their free time, without being considered (as unfortunately happens in other sports) an imposition by parents. This game contributes to a good physical development; moreover, its constant practice will avoid the onset of sedentariness or pathologies such as obesity, very common factors in children. In addition, it has been demonstrated that aerobic physical exercise of moderate intensity, such as that generated by the game of Paddle, can help lose weight, lower blood pressure, and reduce the risk of heart attacks and heart diseases. The most involved parts of the body during the game of Paddle are the upper limbs, as the speed of play requires their continuous use, with exchanges of hits from both sides. This benefits the upper limbs by improving coordination and muscles, and the movements made to strike the ball with the racket are many and varied. In addition, other parts of the body such as the abdomen and lower limbs are well trained too. As mentioned above, in addition to the positive aspects from the physical point of view, we must not overlook the emotional and psychological ones, which are fundamental in the early stages of the child's growth and development, and thanks to the dynamics of this sport, it allows them to work together and create, game after game, the motivation to improve.

Ultimately, whatever the age, there are benefits both physically and socially when playing the game of Paddle:

- Improved coordination, agility, reactivity, strength, and muscle tone.

- Improved social aspect, as socialization is fostered by making new friends or strengthening previous friendships.

- $\quad$ Increased self-esteem and desire for improvement.

- Greater self-discipline.

- $\quad$ Like all other sports, it turns out to be important to counter everyday life stress.

\section{THE GAME OF PADDLE AT THE TIME OF COVID-19}

To fully understand the situation due to this pandemic and how a sport such as Paddle can be helpful, it is necessary to take a quick look at COVID-19. Coronaviruses are a large family of viruses known to cause illnesses ranging from the common cold to more serious diseases such as Middle East Respiratory Syndrome (MERS) and Severe Acute Respiratory Syndrome (SARS). They were identified in the mid-1960s and are known to infect humans and some animals, with the primary target cells being the epithelial cells of the respiratory and gastrointestinal tracts. The disease caused by the new Coronavirus has a name: "COVID19 ", where "CO" stands for corona, "VI" for virus, " $D$ " for disease and "19" indicates the year in which it appeared. Current evidence suggests that it spreads among people:

- Directly,

- Indirectly (through contaminated objects or surfaces),

- By close contact with infected persons through secretions from the mouth and nose (saliva, respiratory secretions, or droplets). 
So, when a sick person coughs, sneezes, talks, sings, or plays sports near others, these secretions are released from the mouth or nose, and people who are in close contact (at a distance of less than 1 meter/3 feet) with the infected person, can become infected if the droplets enter their mouth, nose, or eyes.

To avoid contact with these droplets, it is important to stay at least 1 meter/3 feet away from others, wash one's own hands frequently and cover one's own mouth and nose with a handkerchief or bent elbow when sneezing or coughing; in addition, in case that physical distancing (standing 1 meter $/ 3$ feet or more away) is impossible, an important measure to protect others is to wear a mask, and it is essential to wash one's own hands frequently.

In Italy, the first two cases of the 2020 COVID-19 pandemic were confirmed on January 30,2020 , due to two tourists coming from China and tested positive for SARS-CoV-2 in Rome. Subsequently, an outbreak of infections was reported again on February 20, 2020, with 16 confirmed cases in Codogno (Region of Lombardy, in the province of Lodi), which increased to 60 the following day with the first deaths reported in the same days. On March 11, 2020, the "\#loRestoaCasa Decree" was published, a measure valid on the whole Italian territory until April 3, 2020, suspending all common retail business activities, educational activities, food services, and where assemblies of people in public places or open to the public were prohibited, thus any form of sports activity was prohibited too. The measures taken were further extended until May 3, 2020.

Given the improvement of the situation, on April 26, 2020, the Italian Prime Minister Giuseppe Conte announced, with a new Prime Ministerial Decree (effective from May 4, 2020), the beginning of the so-called "Phase 2", i.e., a gradual easing of the previous containment measures, as the epidemic curve appeared to be descending. This included the opening of public parks, take-away service for catering activities, the reopening of various wholesale production activities and bathing establishments, and allowed carrying out motor activities regardless of the distance from one's home, on condition that these were not contact sports.

On June 11, the so-called "Phase 3" began, and a new Prime Ministerial Decree was published, effective from June 15 to July 14, 2020, which further eased the restrictions.

With the beginning of post-Coronavirus Phase 2, it was possible to start practicing some sports again, as the practice of team sports such as football, basketball and volleyball remained prohibited. In the classification of the most suitable sports at the time of Coronavirus, Paddle is certainly among the first ones, as it is not a contact sport and, in this period, it is practiced almost exclusively outdoors; in fact, it is also for this reason that this sport, which was already spreading quickly, manages to become popular even faster, so much so that it can be defined as a real social phenomenon involving hundreds of people every month, from children to people over sixty.

To make it possible to practice this sport, a real code of conduct to be respected has been established, involving the following:

- Always wear a mask when approaching the courts, and always carry sanitizing gel in your racket bag.

- Always maintain a safe distance and stay at least one meter/three feet behind the others, during and after playing Paddle, especially if you are playing in pairs.

- The handshake, or the "high-five", can be replaced with touching the tip of the paddle with that of your game partner.

- Wash your hands thoroughly before and after the match and use sanitizing gel as soon as possible. 
Generally, this sport is played 2 vs 2 but, because of the restrictions due to the pandemic, it is also possible to play it 1 vs 1 ; moreover, it must be considered that the risks of contagion in the game of Paddle are really minimal, as it is performed outdoors and in a 10-meter court, without any contact neither with the teammate nor with the two opponents. In addition, it must also be considered that even only family members can practice it, for example by creating real challenges between parents and children, thus reducing the risk of contagion to zero.

Numerous scientific studies have shown the positive influence of physical activity on the immune system, especially if practiced consistently and without excess. Indeed, it is well known that regular physical activity, with the right duration and intensity, helps improve the immune response of the body. In addition, it has been highlighted the importance that this sport has taken on from a social and relational point of view, especially in a period in which, due to the pandemic, it was not possible to practice any sports activity, thus eliminating any form of social relationship. In fact, this forced suspension could have been useful to demonstrate once again, if it came down to it, that the social-relational aspect is inherent in Paddle as well as in any other sports activity, values that apparently seem to be taken for granted, but that have taken on greater importance during the pandemic period, in which it was forbidden to have any form of contact with anyone who was not part of one's own family nucleus.

In addition, we must not overlook any socialization difficulties that may arise as a consequence of the pandemic; in fact, both children and adults have had difficulty in "re-socializing" with the outside world, as during the lockdown period the only way to communicate with others was through the use of information technology (computer, cell phone, chat, video calls, and so on). This assumption makes it clear how the practice of Paddle can be useful to "restore" social normality, as it promotes a gradual contact with others by respecting the rules imposed and any socialization difficulties that may arise.

Therefore, practicing a sport such as Paddle, able to reduce the risk of contagion thanks to the way it is played (distance from one's opponent or teammate always greater than one meter/three feet), generates positive effects both from a physical and also (and above all from) an educational-relational point of view, so much so that it could be defined as a "socially useful" sport.

\section{CONCLUSIONS}

Any sports expression, including Paddle, has an important educational aspect that is usually little considered. The onset of the COVID-19 pandemic has shown that the practice of this sport must be considered as a bearer of educational but also and above all social values. The practice of this game must be understood as a fertile ground for the development of friendship due to the collaboration between teammates, who must cooperate in order to achieve a common goal, but also between opponents who challenge each other for the sake of doing it in a healthy competition. This sport can be defined as a useful tool to achieve and satisfy certain social values, which can be used and expanded through the practice of this sport, and the many bodily and social experiences that are generated.

It is in this perspective that Paddle aims to increase the educational and social potential of each individual, managing to act as a support to help overcome any difficulties that may arise both during and after the pandemic due to COVID-19. 


\section{REFERENCES}

Ausubel, D. (2004). Educazione e processi cognitivi. Guida psicologica per gli insegnanti. Milan: Franco Angeli Editor.

Benetton, M. (2015). Allenamento per la vita. L'educazione sportivo-motoria for life.

Boscariol, G. P. (2020). Le disposizioni emergenziali COVID-19 e le limitazioni all'attività motoria: analisi comparata delle ordinanze regionali nella cd Fase 2. Rivista giuridica del Mezzogiorno, 34(2), 425447.

Brezinka, W. (2011). Educazione e pedagogia in tempi di cambiamento culturale. Milan: Vita e pensiero Editor.

Castillo-Lozano, R., \& Casuso-Holgado, M. J. (2017). Incidence of musculoskeletal sport injuries in a sample of male and female recreational paddle-tennis players. The Journal of sports medicine and physical fitness, $57(6), 816-821$.

Castillo-Rodríguez, A., Alvero-Cruz, J. R., Hernández-Mendo, A., \& Fernández-García, J. C. (2014). Physical and physiological responses in Paddle Tennis competition. International Journal of Performance Analysis in Sport, 14(2), 524-534. https://doi.org/10.1080/24748668.2014.11868740

Carraro, A., \& Marino, M. (2016). Lo sport che educa: tra miti e realtà. Formazione \& Insegnamento. Rivista internazionale di Scienze dell'educazione e della formazione, 14(3), 11-24.

Carrasco, L., Corrales, B. S., \& Lora, M. D. H. (2007). Analysis of the paddle tennis practice: a healthful sport for all. Universitatis Palackianae Olomucensis Gymnica, 37(2), 31.

Ceciliani, A. (2018). Didattica integrata quali-quantitativa, in educazione motoria-sportiva, e benessere in età evolutiva. Formazione \& Insegnamento. Rivista internazionale di Scienze dell'educazione e della formazione, 16(1), 183-194.

Cereda, F. (2016). Attività Fisica e Sportiva: tra l'educazione della persona e le necessità per la salute. Formazione \& Insegnamento. Rivista internazionale di Scienze dell'educazione e della formazione, 14(3), 25-32.

Coco, D. (2014). Lo straordinario valore educativo dello sport. Formazione \& Insegnamento. Rivista internazionale di Scienze dell'educazione e della formazione, 12(3), 119-132.

Destrini, G. (2007). Le potenzialità formative dello sport - L'attività sportiva tra educazione e formazione.

Di Palma, D., \& Tafuri, D. (2016). Special needs and inclusion in sport management: a specific literature review. Sport Science, 9(Suppl. 2), 24-31.

Farinelli, G. (2005). Pedagogia dello sport ed educazione della persona (Vol. 3). Morlacchi Editor.

Hughes, D., Saw, R., Perera, N. K. P., Mooney, M., Wallett, A., Cooke, J., ... \& Broderick, C. (2020). The Australian Institute of Sport framework for rebooting sport in a COVID-19 environment. Journal of Science and Medicine in Sport. https://doi.org/10.1016/.jsams.2020.05.004

Isidori, E., \& Fraile, A. (2008). Educazione, sport e valori. Un approccio critico-riflessivo. Rome: Aracne Editor.

Lazzerini, M., \& Putoto, G. (2020). COVID-19 in Italy: momentous decisions and many uncertainties. The Lancet Global Health, 8(5), e641-e642. https://doi.org/10.1016/S2214-109X(20)30110-8

Lapierre, A. (2001). Dalla psicomotricità relazionale all'analisi corporea della relazione. Rome: Armando Editor.

Le Boulch, J. (1979). Educare con il movimento. Rome: Armando Editor.

Mari G., (A cura di), Pedagogia del movimento e della corporeità (pag. 97) Milan: Vita e Pensiero Editor. Mialaret, G. (1997). Le funzioni educative dello sport. Documentos técnicos. Varese.

Naccari, A. G. A. (2003). Pedagogia della corporeità. Educazione, attività motoria e sport nel tempo, Perugia: Morlacchi Editor. 
Pellai, A., \& Pellai, P. (1998). Giocare con lo sport. La guida per crescere con lo sport (Vol. 72). FrancoAngeli Editor.

Peri V., Anno europeo 2004, educare attraverso lo sport, in Settimana - 11 gennaio 2004/n.1.

Porro, N. (2006). L'attore sportivo: azione collettiva, sport e cittadinanza. La meridiana Editor.

Raiola, G., Lipoma, M., \& Tafuri, D. (2015). Postural control in young soccer players: differences between the cognitive approach and ecological-dynamic one. Journal of Human Sport and Exercise 10(Special Issue), pp. S385-S390. https://doi.org/10.14198/ihse.2015.10.Proc1.29

Raiola, G., Tafuri, D. (2015). Teaching method of physical education and sports by prescriptive or heuristic learning. Journal of Human Sport and Exercise, 10(Special issue), pp. S377-S384. https://doi.org/10.14198/ihse.2015.10.Proc1.28

Schram, B. (2015). Stand up paddle boarding: an analysis of a new sport and recreational activity (Doctoral dissertation, Bond University).

Sibilio, M. (2005). Lo sport come percorso educativo. Naples: Alfredo Guida Editor.

Terrone G., Santona A. (2012) II rischio psicopatologico in preadolescenza. Giornale italiano di psicologia, 39(3), 2012, pp.697-706.

Terrone G., Di Sarno V., Ferri R., Lucarelli L. (2014) Development of personal and social autonomy in teenagers and young adults with Down Syndrome: an empirical study on self-representations in family relationships. Life Span and Disability, 17(2), 2014 pp. 223-244.

Waydia, S. E., \& Woodacre, T. (2016). Paddle-boarding: fun, new sport or an accident waiting to happen?. Trauma monthly, 21(3). https://doi.org/10.5812/traumamon.19299

\section{(9) $(\Theta \Theta \Theta$}

This work is licensed under a Attribution-NonCommercial-NoDerivatives 4.0 International (CC BY-NC-ND 4.0). 